\title{
PENGARUH KONSENTRASI PUPUK ORGANIK CAIR SERTA VARIETAS DAN GALUR TERHADAP PERTUMBUHAN DAN PRODUKSI BENIH TANAMAN KACANG PANJANG (Vigna sinensis (L.) Savi ex Hassk.)
}

(The Effect of Liquid Organic Fertilizer Concentracion and Varieties and Strains On Growth and The Seed Production of Long Bean Plants (Vigna sinensis (L.) Savi ex Hassk.)

\author{
Arnandha Desya Refaldi, Pras odjo Soedomo, Muharam, Yayu Sri Rahayu \\ Program Studi Agroteknologi, Fakultas Pertanian, Universitas Singaperbangsa Karaw ang \\ Jl. HS. Ronggo Waluyo, Karawang 41361, Jawa Barat, Indonesia \\ Penulis Koresponden : arnandharefaldi@gmail.com
}

Article Submitted: 16-04-2021

Article Accepted: 03-08-2021

\begin{abstract}
Long bean production in Indonesia continues to decline every year, this is due to land conversion and the lack of application of agricultural technology. One of the efforts to increase long bean production is by multiplying quality seeds using organic materials as nutrients needed by plants. This study aims to determine the response of the growth and production of long bean seeds to the interaction of strains, varieties with a concentration of liquid organic fertilizer. The research was conducted at the Vegetable Crops Research Institute, Lembang, West Bandung Regency from July 2020 to January 2021. The research method used was an experimental method with a Randomized Block Design (RBD) with a split-plot design consisting of 2 factors: the first factor (main plot) (A) was the variety and strain with 2 levels, a (Tavi canton variety) and $\mathrm{a}_{2}$ (pras-1 strain).The second factor (subplot) (B) is concentration of biopras- 1 with 5 levels, $b_{1}\left(0 \mathrm{cc} / \mathrm{l}^{-1}\right.$ water $), b_{2}\left(1 \mathrm{cc} / \mathrm{l}^{-1}\right.$ water $), \mathrm{b}_{3}\left(2 \mathrm{cc} / \mathrm{I}^{-1}\right.$ water $), \mathrm{b}_{4}\left(3 \mathrm{cc} / \mathrm{l}^{-1}\right.$ water $)$ and $\mathrm{b}_{5}\left(4 \mathrm{cc} / \mathrm{l}^{-1}\right.$ water $)$. The effect of the treatment was analyzed by means of variance and if the f test at $5 \%$ level was significantly different, then to find out the best treatment was continued with the DMRT (Duncan Multiple Range Test) at the 5\% level. The results showed that there was an interaction between varieties, lines with various concentrations of biopras-1 liquid organic fertilizer on dry seed weight per plant, dry seed weight per plot, and 1000 seeds weight. Treatment of pras-1 lines with the concentration of liquid organic fertilizer biopras-1 $4 \mathrm{cc} / 1$ of water was able to give the best results on dry seed weight per plant (35.31 gr), dry seed weight per plot (1.298.20 gr or 2.16 $\mathrm{Ton} / \mathrm{ha}^{-1}$ ) and the weight of 1000 seeds (153.10 gr).
\end{abstract}

Keywords : Production of seeds, long beans, varieties, strains, biopras-1.

\section{PENDAHULUAN}

Kacang panjang merupakan tanaman sayuran yang banyak ditemukan di Indonesia khususnya di dataran rendah. Menurut Ardian, Aryawan \& Ginting (2016), tanaman kacang panjang termasuk dalam famili Papilionaceae/Leguminosae dan termasuk ke dalam tanaman semusim. Di Indonesia, kacang panjang menempati posisi 8 dari 20 jenis sayuran yang sering dikonsumsi masyarakat (Lamtiar, 2010).

Kacang panjang memiliki kandungan gizi yang cukup tinggi dalam 100 gram, seperti 2,7 g (protein), 0,3 g (lemak), 7,8 g (karbohidrat), dan 4,9 g (kalsium) (Sunarjono, 2012). Oleh karena itu, kacang panjang menjadi sumber protein sekaligus sumber gizi yang murah 
dan mudah dibudidayakan di berbagai wilayah Indonesia. Menurut Soedomo (2013), kacang panjang memiliki potensi daya hasil hingga mencapai lebih dari 15 ton/ha.

Produksi, dan luas areal penanaman kacang panjang setiap tahunnya mengalami penurunan, berdasarkan data BPS (2019), produksi kacang panjang (2017) mencapai 381.189 ton dengan luas areal penanaman 56.111 ha dan jumlah konsumsi mencapai 4,37 $\mathrm{kg} / \mathrm{kapita} / \mathrm{tahun}, \quad$ sedangkan produksi kacang panjang (2018) mengalami penurunan menjadi 370.225 ton dengan luas areal penanaman 53.405 ha dan jumlah konsumsi mencapai 4,83 kg/kapita/tahun. Hal ini menunjukkan bahwa produksi kacang panjang belum mampu memenuhi kebutuhan konsumsi masyarakat yang cenderung meningkat setiap tahunnya.

Produksi kacang panjang yang terusmenerus mengalami penurunan setiap tahunnya disebabkan oleh beberapa faktor seperti, terbatasnya ahli perbenihan (pemulia) sehingga masih sedikit benih unggul, pengunaan benih tidak bersertifikat oleh petani, teknik budidaya, hingga alih fungsi lahan.

Penerapan budidaya tanaman dan pemuliaan tanaman merupakan beberapa cara yang dapat dilakukan dalam meningkatkan produktvitas suatu tanaman (Yuliawati et al, 2018). Pemuliaan tanaman merupakan salah satu upaya dalam meningkatkan produktivitas kacang panjang. Kegiatan pemuliaan tanaman sudah dilakukan sejak dahulu melalui persilangan beberapa varietas untuk menciptakan galurgalur yang memiliki sifat unggul.

Menurut Witcombe et al dalam Hairmansis et al (2015), galur merupakan tanaman hasil pemuliaan yang telah diseleksi dan diuji, memiliki sifat-sifat unggul yang sesuai dengan tujuan pemuliaan tetapi belum dilepas sebagai varietas.

Beberapa galur kacang panjang yang berasal dari hasil persilangan seperti pras-1, pras-2 dan lainnya perlu melalui proses tahapan pengujian agar galur kacang panjang tersebut dapat dilepas sebagai varietas unggul.

Selain itu, benih memiliki peran penting dalam menghasilkan produktivitas tanaman yang optimum. Saat ini, banyak ditemukan petani yang masih menggunakan benih tidak bersertifikasi, hal ini bertujuan untuk menekan biaya operasional budidaya tanaman.

Varietas atau benih unggul banyak memiliki manfaat bagi petani dalam menjalankan budidaya tanaman baik secara teknis maupun ekonomis seperti pertumbuhan tanaman menjadi seragam, panen serempak, lebih tahan dari serangan hama maupun penyakit dan menjaga keaslian atau kemurnian genetik yang dihasilkan oleh pemulia bisa dirasakan manfaatnya hingga ke tangan petani (Sodikin, 2015).

Di Indonesia, varietas unggul kacang panjang dapat dengan mudah kita temukan di toko pertanian seperti varietas kanton tavi, kp-1, katrina, parade tavi, wulung dan lainnya. Pemakaian varietas unggul dapat menjadi solusi bagi petani untuk meningkatkan produksi dan memenuhi kebutuhan kacang panjang.

Faktor lain yang menyebabkan penurunan produksi kacang panjang yaitu pemakaian pupuk anorganik secara terus menerus dan tidak memperhatikan dosis, sehingga hal ini mengakibatkan kerusakan pada lingkungan seperti kesuburan tanah, mengganggu pertumbuhan tanaman, dan menambah polusi lingkungan yang berpengaruh pada kesehatan manusia (Lingga dan Marsono, 2001).

Penggunaan pupuk organik menjadi salah satu pilihan yang dapat dilakukan dalam menunjang pertumbuhan tanaman kacang panjang, sehingga produktivitas dan mutu benih yang dihasilkan dapat meningkat tanpa memberi efek negatif pada lingkungan. Berdasarkan bentuk, pupuk organik terdiri dari padat dan cair. Hasinar dan Bahrum (2015) mengemukakan, 
pupuk organik cair (poc) adalah jenis pupuk berbentuk cairan yang berasal dari hasil dekomposisi mikroorganisme, kotoran hewan, manusia dan sisa-sisa tanaman yang mengandung unsur hara mikro maupunmakro esensial. Penggunaan pupuk organik cair akan memberikan pengaruh dalam penyediaan dan mengatasi kekurangan unsur hara secara cepat bagi suatu tanaman (Karolus, 2017). Berdasarkan hasil penelitian yang dilakukan oleh Muthmainnah (2013), hasil rata-rata tertinggi berat berangkas basah polong kacang panjang $(280,48$ gr $)$ dan berat berangkas kering $(27,79$ gr) dihasilkan pada perlakuan konsentrasi poc $2 \mathrm{cc} / \mathrm{l}$ air.

Berbagai unsur hara mikro dan makro esensial seperti kadar C organik yang tinggi, $\mathrm{N}, \mathrm{P}, \mathrm{K}, \mathrm{Mg}, \mathrm{Mn}, \mathrm{Fe}$, dan $\mathrm{Cu}$ terkandung pada pupuk organik cair (Makiyah, 2013). Sinta (2008) menambahkan, salah satu kelebihan dari penggunaan pupuk organik cair yaitu mampu memperbaiki susunan atau agresasi tanah (pasir, debu, liat), ramah lingkungan, murah dan mudah didapatkan.

\section{METODE PENELITIAN}

\section{Tempat dan Waktu}

Penelitian dilaksanakan di Balai Penelitian Tanaman Sayuran, Desa Cikole, Lembang, Bandung Barat, Jawa Barat, dengan ketinggian tempat $1.250 \mathrm{mdpl}$ pada bulan Juli 2020 sampai Januari 2021.

\section{Bahan dan Alat}

Bahan yang digunakan yaitu pupuk organik cair Biopras-1 (BP-1), benih kacang panjang varietas Kanton Tavi, galur Pras 1, air, pupuk kandang, pupuk NPK (16:16:16), dolomit, herbisida, pestisida, cat, kuas, MPHP dan plastik. Alat yang digunakan yaitu bajak rotari, bajak piring, cangkul, lanjaran/turus, penggaris, tali rafia, selang, hand sprayer, gelas ukur, ember, kayu, pulpen, kertas, gunting, handphone/kamera, laptop, pelubang mulsa dan timbangan digital.

\section{Rancangan Pene litian}

Penelitian ini menggunakan metode eksperimental dengan Rancangan Acak Kelompok (RAK) pola split plot yang terdiri dari dua faktor dan diulang sebanyak tiga kali. Faktor pertama (petak utama) adalah varietas dan galur (A) dengan dua taraf yaitu, $a_{1}$ (varietas kanton tavi) dan $\mathrm{a}_{2}$ (galur pras-1). Sedangkan faktor kedua (anak petak) adalah konsentrasi pupuk organik cair biopras-1 (B) dengan lima taraf yaitu, $b_{1}(0$

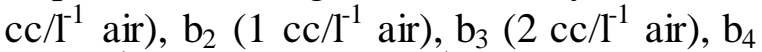
$\left(3 \mathrm{cc} / \mathrm{I}^{-1}\right.$ air $)$ dan $b_{5}\left(4 \mathrm{cc} / \mathrm{l}^{-1}\right.$ air $)$.

\section{Pengumpulan Data}

Variabel penelitian yang diamati terdiri dari : (1) jumlah tanaman yang hidup 30 hst, (2) umur tanaman saat berbuah 50\% per petak, (3) bobot biji kering per tanaman, (4) bobot biji kering per petak dan (5) bobot 1000 biji.

\section{Analisis Data}

Data hasil penelitian dianalisis dengan sidik ragam uji $\mathrm{F}$ taraf 5\%. Jika terdapat pengaruh nyata atau interaksi akan dilakukan uji lanjut menggunakan Duncan Multiple Range Test (DMRT) pada taraf 5\% (Gomez dan Gomez, 1995).

\section{HASIL DAN PEMBAHASAN}

\section{Jumlah Tanaman Yang Hidup 30 hst}

Hasil analisis sidik ragam menunjukkan bahwa pelakuan varietas, galur dan berbagai pemberian konsentrasi biopras-1 (BP-1) tidak berpengaruh nyata terhadap parameter jumlah tanaman yang hidup 30 hst. 
Tabel 1. Rerata Jumlah Tanaman Yang Hidup 30 hst Pada Varietas, Galur dan Konsentrasi Pupuk Organik Cair Biopras-1 (BP-1)

\begin{tabular}{|c|c|}
\hline Perlakuan & Rata-rata Jumlah Tanaman \\
\hline Varietas, Galur (A) & Yang Hidup 30 hst \\
\hline $\mathrm{a}_{1}$ (varietas kanton tavi) & $39.87 \mathrm{a}$ \\
\hline $\mathrm{a}_{2}($ galur pras- 1$)$ & $39.87 \mathrm{a}$ \\
\hline $\mathrm{KK}(\%)$ & 1.59 \\
\hline \multicolumn{2}{|l|}{ Konsentrasi Biopras-1 (B) } \\
\hline $\mathrm{b}_{1}\left(\mathrm{o} \mathrm{cc} / \mathrm{I}^{-1}\right.$ air $)$ & $40.00 \mathrm{a}$ \\
\hline $\mathrm{b}_{2}\left(1 \mathrm{cc} / \mathrm{l}^{-1}\right.$ air $)$ & $39.67 \mathrm{a}$ \\
\hline$b_{3}\left(2 c c / l^{-1}\right.$ air $)$ & $40.00 \mathrm{a}$ \\
\hline $\mathrm{b}_{4}\left(3 \mathrm{cc} / /^{-1}\right.$ air $)$ & $39.67 \mathrm{a}$ \\
\hline$b_{5}\left(4 c c / l^{-1}\right.$ air $)$ & $40.00 \mathrm{a}$ \\
\hline $\mathrm{KK}(\%)$ & 1.30 \\
\hline
\end{tabular}

Perlakuan varietas Kanton Tavi $\left(a_{1}\right)$ menghasilkan nilai rata-rata sebesar 39,87 tanaman, tidak berbeda nyata dengan galur Pras-1 $\quad\left(a_{2}\right)$ sebesar 39,87 tanaman. Sedangkan pada perlakuan konsentrasi pupuk organik cair BP-1 $2 \mathrm{cc} / \mathrm{l}^{-1}$ air $\left(\mathrm{b}_{3}\right), 4$ $\mathrm{cc} / \mathrm{l}^{-1}$ air $\left(\mathrm{b}_{5}\right)$ dan $0 \mathrm{cc} / \mathrm{l}^{-1}$ air (kontrol) $\left(\mathrm{b}_{1}\right)$ menghasilkan nilai rata-rata tertinggi terhadap jumlah tanaman yang hidup 30 hst sebesar 40 tanaman, tidak berbeda nyata dengan perlakuan konsentrasi lainnya.

Salah satu faktor yang diduga menyebabkan tidak adanya pengaruh nyata pada perlakuan konsentrasi BP-1 terhadap jumlah tanaman yang hidup 30 hst yaitu nilai derajat keasaman sebesar 6,58 dan bersifat asam yang terkandung dalam BP-1. Hal ini menunjukkan bahwa BP-1 dapat mendukung pertumbuhan tanaman secara optimal. Menurut Ayu (2016), salah satu syarat tumbuh untuk tanaman kacang panjang dapat tumbuh baik dan optimal yaitu membutuhkan $\mathrm{pH}$ berkisar 5,5-6,6.
Selain itu, faktor lain yang mempengaruhi tanaman dapat tumbuh dengan baik dan normal adalah benih. Hasil pengamatan yang diperoleh pada (Tabel 1) menunjukkan, bahwa persentase tanaman yang hidup 30 hst dari masing-masing pemberian berbagai konsentrasi BP-1 diatas 90\%. Direktorat Perbenihan Hortikultura (2012) mengemukakan, bahwa benih kacang panjang dapat dinyatakan benih bermutu apabila memiliki kadar air maksimum $11 \%$, tercampur dengan benih tanaman lain maksimal $0,1 \%$, kemurnian benih minimal $99 \%$, benih kotor maksimal $1 \%$ dan daya kecambah minimal $85 \%$.

\section{Umur Tanaman Saat Berbuah 50\% Per Petak}

Hasil analisis sidik ragam (Tabel 2) menunjukkan bahwa terdapat pengaruh mandiri pada perlakuan varietas dan galur terhadap parameter rata-rata umur tanaman saat berbuah $50 \%$ per petak. 
Tabel 2. Rerata Umur Tanaman Saat Berbuah 50\% Per Petak (hst) Pada Varietas, Galur dan Konsentrasi Pupuk Organik Cair Biopras-1 (BP-1)

\begin{tabular}{cc}
\hline Perlakuan & $\begin{array}{c}\text { Rata-rata Umur Tanaman Saat Berbuah } \\
50 \% \text { Per Petak (hst) }\end{array}$ \\
\hline Varietas, Galur (A) & $70.00 \mathrm{a}$ \\
$\mathrm{a}_{1}$ (varietas kanton tavi) & $66.53 \mathrm{~b}$ \\
$\mathrm{a}_{2}$ (galur pras-1) & 2.19 \\
\hline KK (\%) & \\
\hline Konsentrasi Biopras-1 (B) & $68.17 \mathrm{a}$ \\
\hline $\mathrm{b}_{1}\left(\mathrm{o} \mathrm{cc/l^{-1 }}\right.$ air) & $68.17 \mathrm{a}$ \\
$\mathrm{b}_{2}\left(1 \mathrm{cc} / /^{-1}\right.$ air) & $67.17 \mathrm{a}$ \\
$\mathrm{b}_{3}\left(2 \mathrm{cc} / /^{-1}\right.$ air) & $69.00 \mathrm{a}$ \\
$\mathrm{b}_{4}\left(3 \mathrm{cc} / /^{-1}\right.$ air) & $68.83 \mathrm{a}$ \\
$\mathrm{b}_{5}\left(4 \mathrm{cc} / /^{-1}\right.$ air) & 2.07 \\
\hline $\mathrm{KK}(\%)$ &
\end{tabular}

Keterangan : Nilai rerata pada kolom yang sama diikuti huruf yang sama tidak berbeda nyata menurut uji DMRT taraf 5\%.

Perlakuan varietas Kanton Tavi $\left(\mathrm{a}_{1}\right)$ menghasilkan nilai rata-rata tertinggi sebesar 70 hst yang berbeda nyata terhadap galur Pras-1 $\left(a_{2}\right)$ sebesar 66,53 hst. Sedangkan pada perlakuan pemberian berbagai konsentrasi pupuk organik cair biopras-1, nilai rata-rata tertinggi dihasilkan pada perlakuan konsentrasi $3 \mathrm{cc} / \mathrm{l}^{-1}$ air $\left(\mathrm{b}_{4}\right)$ sebesar 69 hst.

Berdasarkan hasil pengamatan (Tabel 2) dapat diketahui bahwa galur Pras1 lebih cepat memasuki fase pembuahan dibandingkan dengan varietas Kanton Tavi. Perbedaan karakteristik pada masing-masing varietas dan galur diduga dapat mempengaruhi umur tanaman saat berbuah. Menurut Ikhsan (2019), pertumbuhan vegetatif maupun generatif suatu tanaman dipengaruhi oleh karakteristik genotipe (faktor internal), keadaan tanah, kandungan hara dalam tanah, intensitas penyerapan air, suhu, kelembaban dan intensitas cahaya matahari (faktor eksternal).

Kelembaban merupakan salah satu bagian dari iklim mikro yang berperan dalam menciptakan keadaan lingkungan disuatu areal pertanaman, sehingga secara langsung dapat mempengaruhi proses pertumbuhan tanaman (Widiningsih dalam Noorhadi, 2003). Adapun kelembaban terbagi menjadi dua yaitu kelembaban udara dan tanah. Hardanto et al (2009) menyatakan bahwa kenaikan atau penurunan suhu lingkungan dan kelembaban udara secara tidak langsung akan mempengaruhi suhu maupun kelembaban tanah.

Cunhua et al (2011), serapan hara NPK akan menurun seiring dengan terjadinya penurunan kelembaban tanah, sehingga hal ini menyebabkan penurunan konduktivitas stomata dan pembentukan pigmen fotosintetik.

\section{Bobot Biji Kering Per Tanaman}

Berdasarkan analisis uji DMRT 5\% menunjukkan bahwa terdapat interaksi antara varietas, galur dengan berbagai konsentrasi BP-1 terhadap parameter bobot biji kering per tanaman.

Pada perlakuan varietas Kanton Tavi $\left(\mathrm{a}_{1}\right)$ dengan pemberian konsentrasi BP-1 0 $\mathrm{cc} / \mathrm{l}^{-1}$ air $\left(\mathrm{b}_{1}\right)$ memberikan hasil rata-rata tertinggi yaitu sebesar 11,41 gr, tidak 
berbeda nyata dengan perlakuan $3 \mathrm{cc} / \mathrm{l}^{-1}$ air $\left(b_{4}\right)$ sebesar 11,35 gr.

Tabel 3. Rerata Bobot Biji Kering Per Tanaman Akibat Interaksi Varietas, Galur dan Konsentrasi Pupuk Organik Cair Biopras-1 (BP-1)

\begin{tabular}{|c|c|c|c|c|c|}
\hline \multicolumn{6}{|c|}{ Bobot Biji Kering Per Tanaman (gr) } \\
\hline \multirow{2}{*}{ Varietas, Galur (A) } & \multicolumn{5}{|c|}{ Konsentrasi Biopras-1 (B) } \\
\hline & $\mathrm{b}_{1}\left(0 \mathrm{cc} / \mathrm{l}^{-1}\right.$ air $)$ & $\mathrm{b}_{2}\left(1 \mathrm{cc} / \mathrm{l}^{-1}\right.$ air $)$ & $\mathrm{b}_{3}\left(2 \mathrm{cc} / \mathrm{l}^{-1}\right.$ air $)$ & $\mathrm{b}_{4}\left(3 \mathrm{cc} / \mathrm{l}^{-1}\right.$ air $)$ & $\mathrm{b}_{5}\left(4 \mathrm{cc} / \mathrm{l}^{-1}\right.$ air $)$ \\
\hline \multirow{2}{*}{$\mathrm{a}_{1}$ (varietas kanton tavi) } & $11.41 \mathrm{~b}$ & $5.17 \mathrm{~b}$ & $8.45 \mathrm{~b}$ & $11.35 \mathrm{~b}$ & $2.69 \mathrm{~b}$ \\
\hline & A & $\mathrm{C}$ & B & A & D \\
\hline \multirow{2}{*}{$\mathrm{a}_{2}$ (galur pras- 1$)$} & $35.32 \mathrm{a}$ & $22.99 \mathrm{a}$ & $26.95 \mathrm{a}$ & $30.11 \mathrm{a}$ & $35.31 \mathrm{a}$ \\
\hline & A & $\mathrm{D}$ & $\mathrm{C}$ & B & A \\
\hline KK A & \multicolumn{5}{|c|}{$9.24 \%$} \\
\hline KK B & \multicolumn{5}{|c|}{$6.70 \%$} \\
\hline Keterangan : & $\begin{array}{l}\text { i } \quad \text { rerata ya } \\
\text { tal (arah hor } \\
\text { RT taraf } 5 \% \text {. }\end{array}$ & $\begin{array}{l}\text { diikuti hur } \\
\text { ntal) yang }\end{array}$ & $\begin{array}{l}\text { f kecil (ara } \\
\text { ma, tidak be }\end{array}$ & eda nyata & $\begin{array}{l}\text { n huruf } \\
\text { nurut uji }\end{array}$ \\
\hline
\end{tabular}

Perlakuan galur Pras-1 $\left(\mathrm{a}_{2}\right)$ dengan pemberian konsentrasi BP-1 $0 \mathrm{cc} / \mathrm{I}^{-1}$ air $\left(\mathrm{b}_{1}\right)$ menghasilkan nilai rata-rata terbaik terhadap bobot biji kering per tanaman yaitu sebesar 35,32 gr, tidak berbeda nyata dengan perlakuan konsentrasi $4 \mathrm{cc} / \mathrm{l}^{-1}$ air $\left(\mathrm{b}_{5}\right)$ sebesar 35,31 gr. Hal ini sejalan dengan hasil penelitian Chan (2016), yang menyatakan bahwa hasil tertinggi bobot biji per tanaman kacang hijau sebesar 6,79 gr diperoleh pada perlakuan pemberian dosis poc 150 ml/tanaman. Tadjudin et al (2017) mengemukakan, penggunaan poc (konsentrasi $10 \mathrm{ml} / \mathrm{I}^{-1}$ air) pada kultivar vima-1 mampu memberikan hasil rata-rata terbaik bobot biji kering per tanaman sebesar 7,60 gr.

Unsur hara yang terkandung dalam BP-1 seperti N (4,66\%), P (3,16\%), dan K $(3,84 \%)$ diduga mampu memenuhi kebutuhan unsur hara bagi tanaman. Menurut Widarawati \& Harsojo (2011), unsur hara nitrogen, phospat dan kalium saat pembentukan dan pengisian polong sangat dibutuhkan dalam jumlah yang cukup untuk pembentukan protein pada biji.

\section{Bobot Biji Kering Per Petak}

Hasil analisis uji DMRT 5\% menunjukkan bahwa terdapat interaksi antara varietas, galur dengan berbagai konsentrasi BP-1 terhadap rata-rata bobot biji kering per petak.

Perlakuan varietas Kanton Tavi $\left(\mathrm{a}_{1}\right)$ dengan pemberian konsentrasi BP-1 $3 \mathrm{cc} / \mathrm{l}^{-1}$ air $\left(\mathrm{b}_{4}\right)$ memberikan hasil rata-rata tertinggi sebesar 366,33 gr atau 0.61 ton/ha ${ }^{-1}$.

Hasil rata-rata bobot biji kering per petak terbaik diperoleh pada perlakuan galur Pras-1 $\left(\mathrm{a}_{2}\right)$ dengan pemberian konsentrasi BP-1 $4 \mathrm{cc} / /^{-1}$ air $\left(b_{5}\right)$ yaitu sebesar 1298,20 gr atau 2,16 ton/ha. Tadjudin et al (2017) dalam penelitiannya menyatakan, bahwa hasil rata-rata bobot biji kering per petak tertinggi sebesar $0,367 \mathrm{~kg}$ diperoleh pada perlakuan poc (konsentrasi $10 \mathrm{ml} / \mathrm{l}^{-1}$ air) + kultivar vima-1. 
Tabel 4. Rerata Bobot Biji Kering Per Petak Akibat Interaksi Varietas, Galur dan Konsentrasi Pupuk Organik Cair Biopras-1 (BP-1)

\begin{tabular}{cccccc}
\hline \multicolumn{7}{c}{ Bobot Biji Kering Per Petak (gr) } \\
\hline \multirow{2}{*}{ Varietas, Galur (A) } & \multicolumn{5}{c}{ Konsentrasi Biopras-1 (B) } \\
\cline { 2 - 6 } & $\mathrm{b}_{1}\left(\mathrm{o} \mathrm{cc} / \mathrm{l}^{-1}\right.$ air $)$ & $\mathrm{b}_{2}\left(1 \mathrm{cc} / \mathrm{l}^{-1}\right.$ air $)$ & $\mathrm{b}_{3}\left(2 \mathrm{cc} / \mathrm{l}^{-1}\right.$ air $)$ & $\mathrm{b}_{4}\left(3 \mathrm{cc} / /^{-1}\right.$ air $)$ & $\mathrm{b}_{5}\left(4 \mathrm{cc} / \mathrm{l}^{-1}\right.$ air $)$ \\
\hline \multirow{2}{*}{$\mathrm{a}_{1}$ (varietas kanton tavi) } & $361.33 \mathrm{~b}$ & $230.03 \mathrm{~b}$ & $327.07 \mathrm{~b}$ & $366.33 \mathrm{~b}$ & $219.37 \mathrm{~b}$ \\
& $\mathrm{~A}$ & $\mathrm{~B}$ & $\mathrm{~A}$ & $\mathrm{~A}$ & $\mathrm{~B}$ \\
$\mathrm{a}_{2}$ (galur pras-1) & $1294.43 \mathrm{a}$ & $812.27 \mathrm{a}$ & $886.90 \mathrm{a}$ & $936.27 \mathrm{a}$ & $1298.20 \mathrm{a}$ \\
\hline KK A & $\mathrm{A}$ & $\mathrm{C}$ & $\mathrm{B}$ & $\mathrm{B}$ & $\mathrm{A}$ \\
\hline KK B & \multicolumn{5}{c}{$12.73 \%$} \\
\hline
\end{tabular}

Keterangan : Nilai rerata yang diikuti huruf kecil (arah vertikal) dan huruf kapital (arah horizontal) yang sama, tidak berbeda nyata menurut uji DMRT taraf $5 \%$.

Berdasarkan hasil analisis diatas, pengaruh lingkungan dan genetik dari masing-masing varietas maupun galur diduga menjadi salah satu faktor yang dapat mempengaruhi proses pembentukan biji pada polong. Menurut Siti (2011), lingkungan memiliki peran penting dalam mendukung proses pembentukan ukuran biji yang diproduksi pada suatu tanaman, apabila hasil bobot biji tinggi maka hal ini membuktikan bahwa kemampuan tanaman berdaptasi terhadap cuaca ekstrim sangat baik, akan tetapi faktor yang sangat mempengaruhi ukuran biji hingga mencapai maksimum yaitu faktor genetik.

\section{Bobot 1000 Biji}

Hasil analisis uji DMRT 5\% menunjukkan bahwa terdapat interaksi yang terjadi antara varietas, galur dengan berbagai konsentrasi BP-1 terhadap rata-rata bobot 1000 biji.

Tabel 5. Rerata Bobot 1000 Biji Akibat Interaksi Varietas, Galur dan Konsentrasi Pupuk Organik Cair Biopras-1 (BP-1)

\begin{tabular}{cccccc}
\hline \multicolumn{5}{c}{ Bobot 1000 Biji $(\mathrm{gr})$} \\
\hline \multirow{2}{*}{ Varietas, Galur (A) } & \multicolumn{5}{c}{ Konsentrasi Biopras-1 (B) } \\
\cline { 2 - 6 } & $\mathrm{b}_{1}\left(\mathrm{o} \mathrm{cc} / \mathrm{l}^{-1}\right.$ air $)$ & $\mathrm{b}_{2}\left(1 \mathrm{cc} / \mathrm{l}^{-1}\right.$ air $)$ & $\mathrm{b}_{3}\left(2 \mathrm{cc} / 1^{-1}\right.$ air $)$ & $\mathrm{b}_{4}\left(3 \mathrm{cc} / /^{-1}\right.$ air $)$ & $\mathrm{b}_{5}\left(4 \mathrm{cc} / \mathrm{l}^{-1}\right.$ air $)$ \\
\hline \multirow{2}{*}{$\mathrm{a}_{1}$ (varietas kanton tavi) } & $136.20 \mathrm{~b}$ & $80.87 \mathrm{~b}$ & $105.43 \mathrm{a}$ & $136.30 \mathrm{a}$ & $79.13 \mathrm{~b}$ \\
& $\mathrm{~A}$ & $\mathrm{C}$ & $\mathrm{B}$ & $\mathrm{A}$ & $\mathrm{C}$ \\
$\mathrm{a}_{2}$ (galur pras-1) & $152.30 \mathrm{a}$ & $85.53 \mathrm{a}$ & $99.30 \mathrm{~b}$ & $121.73 \mathrm{~b}$ & $153.10 \mathrm{a}$ \\
\hline KK A & $\mathrm{A}$ & $\mathrm{D}$ & $\mathrm{C}$ & $\mathrm{B}$ & $\mathrm{A}$ \\
\hline KK B & \multicolumn{5}{c}{$7.89 \%$} \\
\hline
\end{tabular}

Keterangan: Nilai rerata yang diikuti huruf kecil (arah vertikal) dan huruf kapital (arah horizontal) yang sama, tidak berbeda nyata menurut uji DMRT taraf 5\%.

Perlakuan varietas Kanton Tavi $\left(\mathrm{a}_{1}\right)$ dengan pemberian konsentrasi BP-1 $3 \mathrm{cc} / \mathrm{l}^{-1}$ air $\left(b_{4}\right)$ memberikan hasil rata-rata tertinggi sebesar 136,30 gr. Sedangkan pada 
perlakuan galur Pras-1 $\left(\mathrm{a}_{2}\right)$ dengan pemberian konsentrasi BP-1 4 cc/ $/^{-1}$ air $\left(b_{5}\right)$, mampu memberikan hasil rata-rata terbaik terhadap bobot 1000 biji yaitu sebesar 153,10 gr, tidak berbeda nyata dengan perlakuan konsentrasi $0 \mathrm{cc} / \mathrm{l}^{-1}$ air $\left(\mathrm{b}_{1}\right)$ sebesar 152,30 gr.

Widiastuti \& Latifah (2016) menyatakan, bobot 100 biji kedelai tertinggi $(17,67$ gr) diperoleh pada varietas burangrang dengan pemberian konsentrasi poc $4 \mathrm{ml} / \mathrm{l}^{-1}$ air. Febra et al (2019) dalam penelitiannya juga menyatakan bahwa berat 100 biji kacang tanah tertinggi $(43,75$ gr) dihasilkan pada perlakuan konsentrasi 10 $\mathrm{ml} / \mathrm{I}^{-1}$ air (poc).

Pemberian BP-1 dengan konsentrasi $4 \mathrm{cc} / \mathrm{l}^{-1}$ air pada galur pras-1 diduga mampu menyediakan unsur hara yang cukup untuk diserap serta ditranslokasikan kebagianbagian tanaman salah satunya biji, sehingga berpengaruh terhadap bobot 1000 biji. Harjadi dalam Febra et al (2019) mengemukakan bahwa unsur hara yang diberikan selama budidaya dapat mempengaruhi metabolisme tanaman seperti fotosintesis. Tingginya proses translokasi hasil fotosintesis ke biji pada suatu tanaman, akan menyebabkan terjadinya kenaikan bobot 100 biji (Kamil, 1996).

\section{KESIMPULAN}

Terdapat interaksi antara varietas, galur dengan berbagai konsentrasi pupuk organik cair BP-1 terhadap bobot biji kering per tanaman, bobot biji kering per plot dan bobot 1000 biji. Perlakuan galur Pras-1 dengan pemberian konsentrasi BP-1 $0 \mathrm{cc} / \mathrm{l}^{-1}$ air (kontrol) menghasilkan nilai rata-rata terbaik terhadap bobot biji kering per tanaman yaitu sebesar 35,32 gr, tidak berbeda nyata dengan perlakuan konsentrasi $4 \mathrm{cc} / \mathrm{l}^{-1}$ air sebesar 35,31 gr. Sedangkan pada perlakuan galur Pras-1 dengan pemberian konsentrasi BP-1 4 cc/ $/^{-1}$ air, mampu menghasilkan nilai rata-rata terbaik terhadap parameter bobot biji kering per plot yaitu
1298,20 gr atau 2,16 ton $/ \mathrm{ha}^{-1}$ dan bobot 1000 biji yaitu 153,10 gr.

\section{UCAPAN TERIMA KASIH}

Drs. Rd. Prasodjo Soedomo, APU selaku pembimbing lapang, Muharam, Ir., MP selaku dosen pembimbing utama, Yayu Sri Rahayu, S.TP., MP selaku dosen pembimbing pendamping dan teman-teman agroteknologi angkatan 16.

\section{DAFTAR PUSTAKA}

Ardian., G. Aryawan., \& Ginting. 2016. Evaluasi Karakter Agronomi Beberapa Genotipe Tetua dan Hibrid Tanaman Kacang Panjang (Vigna sinensis L.) Berpolong Merah. Agrovigor. 1 (9) : 11-18.

Ayu, P. R. 2016. Evaluasi Karakter Vegetatif $\mathrm{F}_{2}$ Kacang Panjang (Vigna sinensis L.) Hasil Persilangan Polong Hijau Rasa Manis dan Polong Merah. Skripsi. Fakultas Pertanian. Universitas Lampung.

BPS [Badan Pusat Statistika]. 2019. Statistik Tanaman Sayuran dan Buah-Buahan Semusim Inonesia 2018. Jakarta.

Chan, H. 2016. Pertumbuhan dan Hasil Kacang Hijau (Vigna radiate L.). Skripsi. Fakultas Pertanian. Universitas Tamansiswa. Padang.

Cunhua S., S. Jian-jie., W. Dan., L. Bai., \& S. Dong. 2011. Effect on Physiological and Biochemical Characteristics of Medicinal Plant Pigweed By Drought Stresses. Medicinal Plants Research. 5 (17) : 4041-4048.

Direktorat Perbenihan Hortikultura. 2012. Pedoman Sertifikasi Benih Tanaman Sayuran. Direktoral Jenderal Hortikultura. Dikutip pada 30 Januari 2021 dari : 
http://ditbenih.hortikultura.pertanian. go.id//index.php?option=com_conten $\mathrm{t} \&$ task $=$ view $\& \mathrm{id}=5 \&$ Itemid $=50$.

Febra, A., H. Yetti., \& S. Yoseva. 2019. Pengaruh Pupuk Cair Limbah Organik Rumah Tangga Terhadap Pertumbuhan dan Produksi Kacang Tanah (Arachis hypogaea L.). Online Mahasiswa. 6 (1) : 1-12.

Gomez, K.A., \& A.A. Gomez. 1995. Statistical procedures for agricultural research (Prosedur statistik untuk penelitian pertanian, alih bahasa E. Syamsuddin, J.S. Baharsyah, dan A.H. Nasution). UI Press. Jakarta.

Hairmansis, A., Supartopo., \& Suwarno. 2015. Seleksi Varietas Partisipatif Terhadap Galur-Galur Elit Padi Gogo di Lahan Petani. Ilmu pertanian. 18 (2) : 61-68.

Hanisar, W., \& A. Bahrum. 2015. Pengaruh Pupuk Organik Cair Terhadap Pertumbuhan dan Hasil Beberapa Varietas Kacang Hijau (Vigna radiata L.). Skripsi. Fakultas Pertanian. Universitas Persatuan Guru Republik Indonesia Yogyakarta.

Hardanto, A., A. Mustofa., \& Sumarni. 2009. Metode Irigasi Tetes dan Perlakuan Komposisi Bahan Organik Dalam Budidaya Stroberi. Keteknikan Pertanian. 23 (1) : 15-24.

Ikhsan, A.G. 2019. Pertumbuhan dan Hasil Kacang Panjang Kultivar Kanton Tavi (Vigna sinensis L.) Akibat Pemberian Kombinasi Dosis Kapur dan Pupuk N. Agrorektan. 6 (1) : 215.

Kamil. 1996. Teknologi Benih. Angkasa Raya, Bandung.
Karolus, Y.P.B. 2017. Pengaruh Pemberian Pupuk Organik Cair Limbah Ikan Nila (Oreochromis niloticus) Terhadap Pertumbuhan dan Produksi Tanaman Kacang Panjang (Vigna sinensis L.). Skripsi. Fakultas Keguruan Dan Ilmu Pendidikan. Universitas Sanata Dharma.

Lamtiar. 2010. Pengaruh Invigorasi Benih Terhadap Pertumbuhan dan Produksi Kacang Panjang (Vigna sinensis (L.) Savi ex Hask) Pada Media Tanah Pantai. Skripsi. Fakultas Pertanian. Institut Pertanian Bogor.

Lingga, P., \& Marsono. 2001. Petunjuk Penggunaan Pupuk. Penebar Swadaya, Jakarta.

Makiyah, M. 2013. Analisis Kadar N, P dan K Pada Pupuk Cair Limbah Tahu Dengan Penambahan Tanaman Matahari Meksiko (Thitonia diversivolia). Skripsi. Fakultas Pertanian. Universitas Negeri Semarang.

Muthmainnah, E. 2013. Pengaruh Pemberian Pupuk Kompos dan Pupuk Organik Cair Terhadap Pertumbuhan Tanaman Kacang Panjang (Vigna sinensis L.). Skripsi. Fakultas Pertanian. Universitas Syiah Kuala Darussalam. Aceh.

Noorhadi, S. 2003. Kajian Pemberian Air dan Mulsa Terhadap Iklim Mikro Pada Tanaman Cabai Di Tanah Entisol. Ilmu tanah dan lingkungan . 4 (1): 41-49.

Sinta, S.S. 2008. Kajian Pemanfaatan Limbah Nilam Untuk Pupuk Cair Organik Dengan Proses Fermentasi. Teknik Kimia. 2 (2) : 1-11. 
Siti, S. 2011. Pendugaan Parameter Genetik dan Metode Seleksi Kedelai (Glycine max (L.) Merril) Berdaya Hasil Tinggi Di Manokwari. Ziraa'ah. 41 (3) : 76-89.

Sodikin, M.D. 2015. Kajian Persepsi Petani dan Produksi Penggunaan Benih Bersertifikat dan Non Sertifikat pada Usaha Tani. Skripsi. Fakultas Pertanian. Universitas Jember.

Soedomo, P.Rd. 2013. Uji Keunggulan Calon Varietas Unggul Kacang Panjang (Vigna sesquipedalis (L.) Fruhw) Di Daerah Blitar. Agrotropika. 18 (2) : 63-72.

Sunarjono, H. 2012. Kacang Sayur. Penebar Swadaya, Bogor.

Tadjudin, E.S., U. Trisnaningsih., \& M.M. Panuntas. 2017. Pengaruh Konsentrasi Pupuk Organik Cair Terhadap Pertumbuhan dan Hasil Pada 3 (Tiga) Kultivar Tanaman Kacang Hijau (Vigna radiate L.). Agroswagati. 5 (2) : 620-634.
Widarawati, R., \& T. Harjoso. 2011. Pengaruh Pupuk P dan K Terhadap Pertumbuhan dan Hasil Kacang Hijau (Vigna radiata L.) Pada Media Tanah Pasir Pantai. Pembangunan Pedesaan. 11 (1) : 67-74.

Widiastuti, E., \& E. Latifah. 2016. Keragaan Pertumbuhan dan Biomassa Varietas Kedelai (Glycine max L.) Pada Lahan Sawah Dengan Aplikasi Pupuk Organik Cair. Ilmu Pertanian Indonesia. 21 (2) : 90-97.

YuliawatI., Y. Wahyu., M. Surahman., \& A. Rahayu. 2018. Keragaman Genetik dan Karakter Agronomi Galur-Galur Kacang Bogor (Vigna subterranea L.Verde.) Hasil Seleski Galur Murni Asal Lanras Sukabumi. Agronida. 4 (1) : 56-63. 